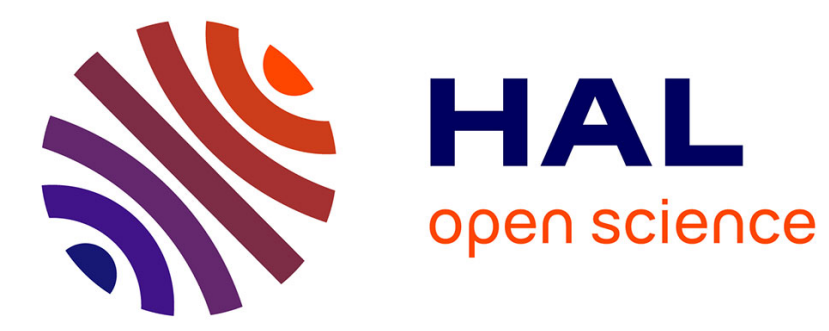

\title{
Grain Orientation and Dislocation Patterns
}

Niels Hansen, Xiaoxu Huang, Wolfgang Pantleon, Grethe Winther

\section{To cite this version:}

Niels Hansen, Xiaoxu Huang, Wolfgang Pantleon, Grethe Winther. Grain Orientation and Dislocation Patterns. Philosophical Magazine, 2006, 86 (25-26), pp.3981-3994. 10.1080/14786430600654446. hal-00513684

\section{HAL Id: hal-00513684 \\ https://hal.science/hal-00513684}

Submitted on 1 Sep 2010

HAL is a multi-disciplinary open access archive for the deposit and dissemination of scientific research documents, whether they are published or not. The documents may come from teaching and research institutions in France or abroad, or from public or private research centers.
L'archive ouverte pluridisciplinaire HAL, est destinée au dépôt et à la diffusion de documents scientifiques de niveau recherche, publiés ou non, émanant des établissements d'enseignement et de recherche français ou étrangers, des laboratoires publics ou privés. 


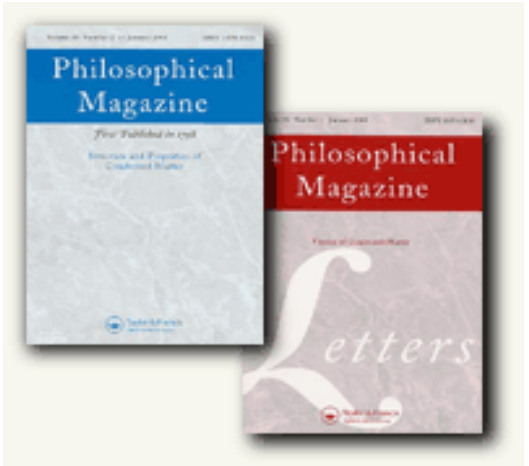

\section{Grain Orientation and Dislocation Patterns}

\begin{tabular}{|c|c|}
\hline Journal: & Philosophical Magazine \& Philosophical Magazine Letters \\
\hline Manuscript ID: & TPHM-05-Oct-0426.R1 \\
\hline Journal Selection: & Philosophical Magazine \\
\hline $\begin{array}{r}\text { Date Submitted by the } \\
\text { Author: }\end{array}$ & 17-Feb-2006 \\
\hline Complete List of Authors: & $\begin{array}{l}\text { Hansen, Niels; Risoe National Laboratory, Materials Research } \\
\text { Department } \\
\text { Huang, Xiaoxu; Risoe National Laboratory, Materials Research } \\
\text { Department } \\
\text { Pantleon, Wolfgang; Risoe National Laboratory, Materials Research } \\
\text { Department } \\
\text { Winther, Grethe; Risoe National Laboratory, Materials Research } \\
\text { Department }\end{array}$ \\
\hline Keywords: & electron microscopy, alloys \\
\hline Keywords (user supplied): & dislocation patterns, dislocation boundaries, dislocation density \\
\hline
\end{tabular}

\section{(s) ScholaroNE" \\ Manuscript Central}




\section{Abstract}

Dislocation patterns have been characterized by transmission electron microscopy and Kikuchi line analysis in pure, polycrystalline aluminium deformed in tension at room temperature in the strain range 0.05-0.34. The angular strain relationship of the dislocation boundaries, their scaling behaviour and the occurrence of similitude shows that two dislocation patterns coexist in all grains, however, with very different characteristics dependent on the grain orientation. An analysis of the hardening behaviour of the grains in the polycrystal and a comparison with single crystal behaviour show a similar strong correlation pointing to the slip pattern as a dominating factor both behind the microstructural evolution and the hardening. An analysis of operating slip systems has underpinned the division of the stereographic triangle based on the microstructural characterization and the hardening behaviour.

\section{Keywords}

Dislocation patterns; dislocation boundaries; dislocation density, flow stress, transmission electron microscopy; Kikuchi line analysis.

\section{Introduction}

In a recent paper Nabarro [1] introduces the sequence of dislocation patterns as deformation proceeds as follows: "While Stages I and II are characteristic of single crystals stressed to induce glide essentially on one system the later stages seem to occur also in single crystals stressed to produce multiple glide, and in polycrystals. These multiple glide configurations are more important technologically and, because they are more symmetrical they may perhaps prove easier to interpret". Both single glide and multiple glide configurations will be discussed in the following based upon quantitative characterization of such structures by transmission electron microscopy and Kikuchi line analysis. The paper will focus on pure FCC metals, single crystals as well as polycrystals, strained in tension at temperatures where the deformation predominantly is by dislocation glide. Within this framework many studies have been carried out over the years, however, with a renewed interest in the last 10-15 years due to the development of fast semiautomatic and automatic techniques with increasing resolution $\sqrt{2}$ ]

The long history of the theme requires a brief introduction of the nomenclature used over the years. This nomenclature was originally introduced to describe the different work hardening stages where for example dipolar mats or walls develop in stage II into a well defined 2D pattern, where dislocation boundaries parallel to the primary slip plane form the characteristic carpet structure. This structure has been analyzed in detail [3-5] and it has been found that the boundaries lie approximately but not exactly parallel to the primary glide plane and are composed of primary dislocation and finely

\begin{tabular}{|c|}
\hline Deleted: [1] \\
\hline Deleted: Mul \\
\hline Deleted: legion of \\
\hline Deleted: [2] \\
\hline Field Code Changed \\
\hline Deleted: [3] \\
\hline Field Code Changed \\
\hline Deleted: Side \\
\hline Deleted: a \\
\hline Deleted: 19 \\
\hline Deleted: 18 \\
\hline $\begin{array}{l}\text { Deleted: http://mc.manuscriptcentral.co } \\
\text { m/LongRequest/pm- } \\
\text { pml?TAG_ACTION=DOWNLOAD_FIL } \\
\text { E\&DOCUMENT_ID=1027263\&FILE_T } \\
\text { O_DOWNLOAD=10771839\&FILE_KE } \\
\text { Y=429685512\&DOWNLOAD=TRUE\& } \\
\text { FILE_TYPE=ORIG_DOCUMENT }\end{array}$ \\
\hline 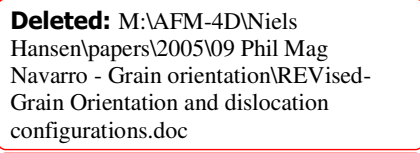 \\
\hline $\begin{array}{l}\text { Deleted: M:\AFM-4DINiels } \\
\text { Hansen\papers } 12005 \backslash 09 \text { Phil Mag } \\
\text { Navarro - Grain orientation } \backslash G W-G r a i n \\
\text { Orientation and dislocation } \\
\text { configurations.doc }\end{array}$ \\
\hline Deleted: 17 February 2006 15:25 \\
\hline Deleted: $2 / 17 / 2006$ 3:25:00 PM \\
\hline Deleted: 04-10-2005 14:58 \\
\hline
\end{tabular}


distributed secondary dislocation These findings have been confirmed by a recent study of a high purity copper single crystal deformed at low strain in tension [6]. The crystal orientation was $11^{\circ}$ from $[110]$ and the extended dislocation boundaries were almost parallel to the primary glide plane $(111)$. The average misorientation angle across the boundaries was $0.2^{\circ}$. A standard contrast analysis in a TEM showed that the boundaries contained primary as well as a few secondary dislocations and that most of the boundaries were of mixed tilt and twist character [6]. Various mechanisms for the formation of the extended boundaries have been suggested $(3,4,5,7,8)$ for example that the boundaries are essentially formed by cross slip of dislocations gliding parallel to the active slip plane $[7,8]$. As deformation proceeds a new structure appears at the beginning of stage III. This structure was termed a cell structure, where a dislocation cell is a volume element (almost) free of dislocations, delineated by dislocation boundaries. Structures with these characteristics have been observed throughout the later work hardening stages and characterized broadly as dislocation cells and subgrains as descriptive (and useful) terms. Characterisation in more detail reveals that structures produced by glide predominantly are composed of extended planar dislocation boundaries delineating cell blocks which are subdivided by cell boundaries. These structures appear in many variations $[2,9,10]$. In the associated nomenclature the extended dislocation boundaries are termed geometrically necessary boundaries (GNBs) because they are assumed to form by a different slip activity on each side of the boundary. The different slip activity may have its cause in operation in neighbouring volumes of different set of slip systems or a different partition of shear among a common set of slip systems[9-11]. The second type of boundaries is termed incidental dislocation boundaries (IDBs) or cell boundaries, which form by mutual trapping of glide dislocations. Deterministic and stochastic processes therefore control the formation and evolution of GNBs and IDBs, respectively. Both types of boundaries are rotational dislocation boundaries with a misorientation angle which increases with the strain, however, with a much faster rate for the GNBs than for the IDBs [12], The dislocations required in order to form a rotational boundary is, however, not per se geometrically necessary dislocations [13] which according to their definition have their cause in strain gradients which build-up during nonhomogenous (non-uniform) deformation [14-16]. Besides the dislocations required in order to form a rotational boundary, the IDBs and GNBs also contain redundant dislocations which decreases in density with increasing strain throughout Stage III as the misorientation angle gradually increases. These characteristic changes including a decrease in the structural scale has been found in a broad range of FCC and BCC metals and alloys deformed by a variety of modes [2]. As an example of the universality of the two types of boundaries they subdivide fcc single crystals deformed in tension [6,17-19], compression [20] and rolling [21]. For polycrystals the structural evolution compares with that of single crystals as observed for grain sizes ranging from several hundred micrometres to sizes as small as a few micrometres [22]. Grain interaction effects may manifest themselves by changes in the microstructure and the local crystallography near grain boundaries and triple junctions. $[23,24]$. However, a much more typical observation is that the interior structure extends to the grain boundaries. These observations can be coupled with an analysis of grain interaction in a high purity polycrystalline copper deformed in tension to a strain of $25 \%$ [25]. A relatively coarse grain size $(\sim 100 \mu \mathrm{m})$ was chosen which allows grain break-up and rotation to be followed as a function of strain using electron back scattering diffraction (EBSD) analysis. Few small domains of special orientations provide evidence of grain interaction. However, the crystal rotation for

\begin{tabular}{|c|}
\hline Deleted: multiple \\
\hline Field Code Changed \\
\hline Deleted: $[2,4,5]$ \\
\hline Deleted: [4-6] \\
\hline Field Code Changed \\
\hline Field Code Changed \\
\hline Deleted: [7] \\
\hline Deleted: [2] \\
\hline Field Code Changed \\
\hline $\begin{array}{l}\text { Deleted: It has also been found in both } \\
\text { single crystals and polycrystals, in the } \\
\text { latter case for grain sizes ranging from } \\
\text { several hundred microns to sizes as small } \\
\text { as a few micrometres [17][8] }\end{array}$ \\
\hline Deleted: Side \\
\hline Deleted: a \\
\hline Deleted: 19 \\
\hline Deleted: 18 \\
\hline $\begin{array}{l}\text { Deleted: http://mc.manuscriptcentral.co } \\
\text { m/LongRequest/pm- } \\
\text { pml?TAG_ACTION=DOWNLOAD_FIL } \\
\text { E\&DOCUMENT_ID=1027263\&FILE_T } \\
\text { O_DOWNLOAD=10771839\&FILE_KE } \\
\text { Y=429685512\&DOWNLOAD=TRUE\& } \\
\text { FILE_TYPE=ORIG_DOCUMENT }\end{array}$ \\
\hline $\begin{array}{l}\text { Deleted: M:IAFM-4DINiels } \\
\text { Hansenlpapers\2005109 Phil Mag } \\
\text { Navarro - Grain orientation\REVised- } \\
\text { Grain Orientation and dislocation } \\
\text { configurations.doc }\end{array}$ \\
\hline $\begin{array}{l}\text { Deleted: M:\AFM-4DINiels } \\
\text { Hansenlpapers } 12005 \backslash 09 \text { Phil Mag } \\
\text { Navarro - Grain orientation\GW-Grain } \\
\text { Orientation and dislocation } \\
\text { configurations.doc }\end{array}$ \\
\hline Deleted: 17 February 2006 15:25 \\
\hline Deleted: $2 / 17 / 2006$ 3:25:00 PM \\
\hline Deleted: 04-10-2005 14:58 \\
\hline
\end{tabular}


the large domains covering most of the grains is consistent with the rotation direction predicted by the Taylor model in some, but not all, cases [25].

\section{Structural analysis}

The present paper analyses in detail the dislocation configurations in pure $(99.99 \%)$ polycrystalline aluminium (grain size $300 \mu \mathrm{m}$ ) strained in uniaxial tension at room temperature. By choosing this mode of deformation the influence of imposed strain gradients, e.g. due to friction, is minimized.

The key issue in the structural analysis is the effect of grain orientation, on the deformation induced microstructures. The structural morphology of grains in the polycrystal is compared with single crystals of similar orientation. Apart from considering the morphology, the approach is to characterize quantitatively microstructural parameters such as spacing between and misorientation across dislocation boundaries and to analyse the evolution of these parameters, e.g. by applying scaling laws and similitude relationships.

\subsection{Microstructure type}

The correspondence between the grain orientation and the morphology of the deformation induced microstructure is illustrated in Fig. 1 [26,27], Based on characterization of a large number of grains three characteristic microstructures were identified each within a specific region of the stereographic triangle [26]:

(i) Type 1 is a cell block structure with planar GNBs delineating volumes within which IDBs are found. The GNBs are almost parallel (within $10^{\circ}$ ) to a slip plane (Middle of triangle).

(ii) Type 2 is a 'classical' cell structure, subdivided by cell boundaries forming an almost equiaxed network of cells (Near [100]).

(iii) Type 3 is a cell block structure like Type 1 but the GNBs are not quite as planar and they lie on crystallographic planes which deviate substantially (up to $35^{\circ}$ ) from the slip planes (Near [111]).

Similar structural types and their orientation dependence have been observed in single crystals deformed in tension. Examples are: Crystal orientation with the [415] tensile axis (Type 1) [17]; crystal orientation with the [100] tensile axis (Type 2) [18,19]; crystal orientation with the [111] tensile axis (Type 3) [18,19].

The rate at which the misorientation angle across and the spacing between the boundaries change with increasing strain is significantly different for GNBs and IDBs. This difference is illustrated in Fig. 2 showing a power law relationship between misorientation angle and strain with a higher slope for the GNBs than for the IDBs in general agreement with the different processes suggested for their evolution [28-30], It is also found that Type 2 grains follow a different power law relationship than the IDBs. Fig. 2 also illustrates an important property of the IDBs namely that their misorientation angle increases almost proportionally with the square root of the applied true strain. This dependency is in direct support of the suggestions that IDBs or cell boundaries form and evolve by statistical trapping of glide dislocations 331. During tensile straining the individual grains rotate and to obtain macroscopic information about this rotation the texture in the undeformed and deformed states has been determined by neutron diffraction [347. From orientation distribution functions (ODFs) the volume fraction of individual orientations have been determined by integrating the density over an angle of $15^{\circ}$ around the ideal position of the

Deleted: The present paper in detail analyses the dislocation configurations in pure $(99.99 \%)$ polycrystalline aluminium (grain size $300 \mu \mathrm{m}$ ) strained in uniaxial tension at room temperature. By choosing this mode of deformation the influence of imposed strain gradients, e.g. due to friction, is minimized. Based on the structure analysis the importance of the grain orientation dependence of the structures for the stress-strain behaviour is discussed.II

Formatted: Bullets and Numbering
Deleted: $[9,10]$

Field Code Changed

Deleted: [9]

Field Code Changed

\begin{tabular}{|c|}
\hline Deleted: . \\
\hline Deleted: . \\
\hline Field Code Changed \\
\hline Deleted: [11-13] \\
\hline Field Code Changed \\
\hline Deleted: [12-16] \\
\hline Deleted: Side \\
\hline Deleted: a \\
\hline Deleted: 19 \\
\hline Deleted: 18 \\
\hline $\begin{array}{l}\text { Deleted: http://mc.manuscriptcentral.co } \\
\text { m/LongRequest/pm- } \\
\text { pml?TAG_ACTION=DOWNLOAD_FIL } \\
\text { E\&DOCUMENT_ID=1027263\&FILE_T } \\
\text { O_DOWNLOAD=10771839\&FILE_KE } \\
\text { Y=429685512\&DOWNLOAD=TRUE\& } \\
\text { FILE_TYPE=ORIG_DOCUMENT }\end{array}$ \\
\hline $\begin{array}{l}\text { Deleted: M:\AFM-4DINiels } \\
\text { Hansen\papers } \backslash 2005 \backslash 09 \text { Phil Mag } \\
\text { Navarro - Grain orientation\REVised- } \\
\text { Grain Orientation and dislocation } \\
\text { configurations.doc }\end{array}$ \\
\hline 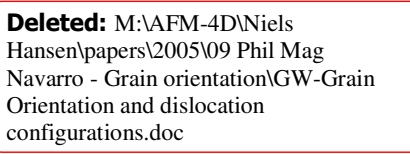 \\
\hline Deleted: 17 February 2006 15:25 \\
\hline Deleted: 2/17/2006 3:25:00 PM \\
\hline Deleted: $04-10-2005$ 14:58 \\
\hline
\end{tabular}


component in the stereographic triangle. To illustrate the textural evolution during straining the volume fractions of [100], [111] and [110] orientations are given in Table 1. The data shows that the $[111]$ component strengthens and that the $[110]$ component weakens in general agreement with predictions by the Taylor model .

\subsection{Scaling and similitude}

The distribution of structural parameters has also been analyzed based on previous findings [35], that both misorientation angles and spacings can be described by a single universal function when each distribution is scaled by its mean angle or spacing. Also previously $[12,36]$ it has been found that the scaling hypothesis applies to both GNBs and IDBs when they are analyzed separately but not when they are grouped together.

It is also observed that a scaled distribution is independent of material type, plastic strain, temperature and deformation conditions [2]. Further the similarity in behaviour of single crystals and polycrystals has been underpinned by the application of the scaling hypothesis to the spacing between GNBs for both single crystals and polycrystals deformed in rolling and compression [2].

In the present structures (Type 1 and Type 3) the misorientation angle and spacing distributions of the GNBs and IDB $\underline{s}$ can be described by single distributions. However, a single function cannot describe the misorientation angle distribution in the Type 2 grains in the [100] region.

A third step in the microstructural analysis has been to apply similitude expressing a fixed relationship between structural parameters [37] e.g. between boundary spacing (D) and the dislocation spacing (h) in a boundary. Taking $\mathrm{h}$ inverse proportional to the misorientation angle $\theta$ similitude can be expressed by the equation $₫ 38$;

$$
\frac{D \theta}{b}=C
$$

where $\mathrm{b}$ is the magnitude of the Burgers vector and $\mathrm{C}$ is a constant. By applying this relationship to the different types of microstructures it is found that IDBs in Type 1 and Type 3 structures have an almost similar behaviour whereas the $\mathrm{C}$ values for the remaining boundaries are higher and show significant variations (see Fig. 3).

The microstructural analysis, the strain dependence of misorientation angles, the application of scaling laws and similitude all suggest a similar structural evolution of the cell block structure in all grains except those in the [100] region with the Type 2 structure. However, to be further explored is the significant difference between the misorientation angles across GNBs in Type 1 and Type 3 structures, respectively (see Fig. 2).

The analysis therefore suggests that the IDBs in Type 1 and Type 3 structures are different from the cell boundaries in Type 2. Based on this finding the cell structure in the [100] region has been analyzed.

\subsection{Structure of [100] grains}

The distribution of misorientation angles, measured by TEM for the Type 2 structure, see Fig. 4, reveals a small fraction of boundaries with misorientation angles significantly larger than the rest indicating a bimodal distribution. A Kikuchi line analysis covering large grain areas has shown that these higher angle boundaries form a regular pattern subdividing the grains on a coarse scale, into regions containing

\begin{tabular}{|l|}
\hline Field Code Changed \\
\hline Deleted: $[17]$ \\
\hline Field Code Changed \\
\hline Deleted: $[7,18]$ \\
\hline
\end{tabular}

\begin{tabular}{|l|}
\hline Deleted: [19] \\
\hline Field Code Changed \\
\hline Deleted: [20] \\
\hline Field Code Changed \\
\hline
\end{tabular}

Deleted: although they all are assumed to be stochastic boundaries

Deleted: D

Deleted: Side

Deleted: a

Deleted: 19

Deleted: 18

Deleted: http://mc.manuscriptcentral.co $\mathrm{m} /$ LongRequest $/ \mathrm{pm}$ -

pml?TAG_ACTION=DOWNLOAD FIL

E\&DOCUMENT_ID $=1027263 \&$ FILE_T O_DOWNLOAD $=10771839 \&$ FILE_KE $Y=429685512 \& D O W N L O A D=T R U E \&$ FILE_TYPE=ORIG_DOCUMENT

Deleted: M:\AFM-4DINiels Hansenlpapers\2005109 Phil Mag Navarro - Grain orientationIREVised Grain Orientation and dislocation configurations.doc

Deleted: M:\AFM-4DINiels Hansenlpapers12005109 Phil Mag Navarro - Grain orientation $\backslash$ GW-Grain Orientation and dislocation configurations.doc

Deleted: 17 February 2006 15:25 Deleted: 2/17/2006 3:25:00 PM Deleted: 04-10-2005 14:58 
small uniform cells, see Fig. 4. This subdivision on two length scales is similar to the formation of a cell block structure. However, the traditional regular pattern of planar GNBs, is replaced by the more equiaxed pattern created by the higher angle boundaries in grains in the [100] region.

An analysis of the distribution of misorientation angles has been carried out for the sample deformed to a strain 0.34. In this sample the average spacing and misorientation angle for the grains in the [100] region is about $2 \mu \mathrm{m}$ and $1.1^{\circ}$, respectively. The analysis showed that the experimental distribution of angles can be decomposed into two distributions. One with an average angle of $0.7^{\circ}$ encompassing $80 \%$ of the boundaries and one with an average angle of $2.2^{\circ}$ covering the rest of the boundaries. This means that for the fine scale structure that the similitude coefficient in Eq. (1) is about 65 in agreement with the values obtained for the IDBs in Type 1 and Type 3 structures (Fig. 3). This finding suggests that also grains in the [100] region form a type of cell block structure when deformed. Note, however, that both the morphology and the size scale of the coarse pattern in the Type 2 grains is significantly different from the characteristics of the cell block structure in Type 1 and Type 3 grains, see Fig. 1.

\section{Discussion}

The microstructural evolution during plastic deformation by dislocation glide is a characteristic subdivision into cell blocks and cells observed both in single crystals and polycrystals. This coexistence of two patterns does, however, not exclude subdivision on an even larger scale, also observed in both single crystals and | polycrystals $\sqrt{2,39,401}$, These patterns characterize structures in the stage III region and they evolve as characteristic low energy dislocation structures, i.e. the dislocations arrange in configurations having the lowest energy per unit length of dislocation line [37]. This energetic approach is applied widely in the analysis of dislocation configuration but it does not have predictive capability. By introducing the mechanics of the problem it has, however, been shown that it is possible to predict one structural parameter namely the GNB inclination in fcc single crystals and polycrystals deformed in plane strain compression [41]. This approach has been to replace a large number of physical slip systems by a pair of equivalent (hypothetical) slip systems and it has been demonstrated that predicted inclinations of GNBs are in good accord with these observed experimentally. Generally, as described in the present paper, a dependence of the morphology and quantitative characteristics of the structure on the grain orientation discovered experimentally, points to the slip pattern as a controlling factor, which furthermore indicates predictability.

\subsection{Structure - slip pattern relations}

Relations between the slip pattern and the occurrence of Type 1, i.e. a cell block structure with GNBs aligning with a slip plane, have been established: in general, the GNBs align with a slip plane when a significant fraction of the total slip is concentrated on that slip plane. This fraction has empirically been determined to be about $45 \%$ [42l but work to included more details of the slip pattern than the slip concentration in structure/slip pattern relations is in progress.

The predictive capabilities of a model based on these relations are of course strongly linked to the ability to predict the slip pattern. The Taylor model is a widely employed model for this but has extensive ambiguity in the selection of slip patterns with five independent systems. For tension the best prediction of grain orientations with slipplane-aligned GNBs is obtained with the solution to the Taylor ambiguity problem,

\begin{tabular}{|c|}
\hline Deleted: polycrystals \\
\hline Deleted: single crystals \\
\hline Deleted: [2,21-23] \\
\hline Field Code Changed \\
\hline Deleted: [19] \\
\hline Field Code Changed \\
\hline Deleted: As \\
\hline Deleted: [24] \\
\hline Deleted: \\
\hline Deleted: predictability \\
\hline Deleted: is \\
\hline Deleted: Side \\
\hline Deleted: a \\
\hline Deleted: 19 \\
\hline Deleted: 18 \\
\hline $\begin{array}{l}\text { Deleted: http://mc.manuscriptcentral.co } \\
\text { m/LongRequest/pm- } \\
\text { pml?TAG_ACTION=DOWNLOAD_FIL } \\
\text { E\&DOCUMENT_ID=1027263\&FILE_T } \\
\text { O_DOWNLOAD=10771839\&FILE_KE } \\
\text { Y=429685512\&DOWNLOAD=TRUE\& } \\
\text { FILE_TYPE=ORIG_DOCUMENT } \\
\end{array}$ \\
\hline 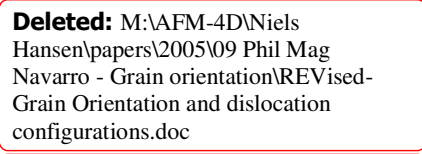 \\
\hline 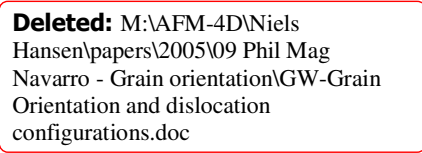 \\
\hline Deleted: 17 February 2006 15:25 \\
\hline Deleted: $2 / 17 / 2006$ 3:25:00 PM \\
\hline Deleted: $04-10-2005$ 14:58 \\
\hline
\end{tabular}


which has most slip on the primary slip system [43]. Selection of this solution is further supported by comparison with data for lattice rotations of individual bulk grains [44], Comparison of the prediction in Fig. 5 with the experimental data in Fig. 1 reveals that the prediction is reasonably good although the location of the transition from Type 1 to Type 3 is not perfectly predicted. It also seems intuitively reasonable that GNBs align with highly active slip planes but lie on other crystallographic planes when no such plane exists. The concept of slip concentration thus reasonably rationalises the differences between Type 1 and Type 3 structures both forming GNBs.

Other features of the slip pattern must, however, be invoked to explain the marked difference between the cell block structure of Type 1 and 3 and the more equiaxed structures of Type 2. Two features, which distinguish the slip patterns of the Type 2 orientations from those of Type 1 and 3 are apparent:

- The number of solutions to the Taylor ambiguity problem is by far the highest close to the $<100>$ corner where at least six solutions are possible. For the orientations forming Type 1 and 3 structures the highest number of solutions is four and the majority of the orientations only have two solutions. The large scale subdivision of the Type 2 structure may have its origin in activation of these different solutions in different parts of the grain/crystal.

- The Type 2 forming orientations are the only orientations in the stereographic triangle where the slip pattern predicted by the Taylor model contains cross slipping systems. Pronounced cross slip means increased dislocation mobility in $3 \mathrm{D}$, i.e. easier access to the equiaxed cell structure.

\subsection{Stress-strain relations}

The significant effect of grain orientation on the evolution of the deformation microstructure suggests that the hardening rate for grains in a polycrystalline sample depend on their crystallographic orientation as also found for single crystals. Fig. 6 illustrates the difference in hardening behaviour of aluminium single crystals having different orientations $[45,46]$, By comparison with the subdivision of the stereographic triangle in Fig. 1 it is seen that the mechanical differences correlate well with the structural differences. This similarity between the microstructural evolution in grains in a polycrystal and the hardening behaviour of single crystals has been further explored based on the quantitative analysis of the microstructural parameters in the deformed polycrystalline samples [34]. This analysis allows the dislocation density to be calculated for the three types of grains in Fig. 1., based on four parameters namely the misorientation across and the spacing between the GNBs and IDBs, respectively. For each type of grain the shear stress strain-strain relationship has been obtained by taking the shear stress proportional to the square root of the dislocation density

$$
\tau=\alpha \mu \boldsymbol{b} \sqrt{\rho}
$$

where $\alpha$ is a number and $\mu$ is the shear modulus and $b$ the magnitude of the Burgers vector. Each of the three types of grain shows characteristic shear stress-strain relationship very similar to those obtained by testing of single crystals, which have been chosen as follows: Crystals on the [100] - [111] line deforming by double slip have been compared to Type 1 grains and crystals of [100] and [111] orientations

Deleted: [25]

Deleted: [26]

Field Code Changed

Deleted: the GNB forming

Deleted: s

Deleted:

Deleted: for

Deleted:

\begin{tabular}{|c|}
\hline Deleted: s \\
\hline Deleted: ists of \\
\hline Deleted: [27,28] \\
\hline Field Code Changed \\
\hline Deleted: $[29,30]$ \\
\hline Deleted: s \\
\hline Deleted: [31] \\
\hline Deleted: $\tau=\alpha \mu \boldsymbol{b} \sqrt{\rho}$ \\
\hline Deleted: (Eq. 2) \\
\hline Deleted: Side \\
\hline Deleted: a \\
\hline Deleted: 19 \\
\hline Deleted: 18 \\
\hline $\begin{array}{l}\text { Deleted: http://mc.manuscriptcentral.co } \\
\text { m/LongRequest/pm- } \\
\text { pml?TAG_ACTION=DOWNLOAD_FIL } \\
\text { E\&DOCUMENT_ID=1027263\&FILE_T } \\
\text { O_DOWNLOAD=10771839\&FILE_KE } \\
\text { Y=429685512\&DOWNLOAD=TRUE\& } \\
\text { FILE_TYPE=ORIG_DOCUMENT }\end{array}$ \\
\hline 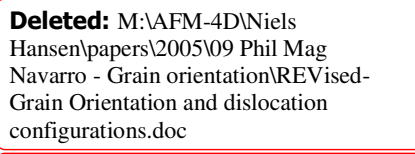 \\
\hline $\begin{array}{l}\text { Deleted: M:\AFM-4DINiels } \\
\text { Hansenlpapers } 2005 \backslash 09 \text { Phil Mag } \\
\text { Navarro - Grain orientation\GW-Grain } \\
\text { Orientation and dislocation } \\
\text { configurations.doc }\end{array}$ \\
\hline Deleted: 17 February 2006 15:25 \\
\hline Deleted: $2 / 17 / 2006$ 3:25:00 PM \\
\hline Deleted: 04-10-2005 14:58 \\
\hline
\end{tabular}


deforming by multislip have been compared with Type 2 and Type 3 grains, respectively $[34$.

The correlation between the hardening of a grain and its crystallographic orientations suggests that the stress-strain relationship for a polycrystalline sample may be approximated by the sum of the hardening of the individual grains. Such an approximation has for the present samples worked satisfactorily as the experimental stress-strain curve could be derived based on the hardening of the single crystals mentioned above, weighted by the experimentally determined volume fraction of | grain orientations with Type 1, 2 and 3 structures, respectively. [34], Deriving the stress-strain curve for a polycrystal from the hardening of a single crystal has been suggested [47] based on the hardening of the [111] crystal. The established relationship between the grain orientation and the deformation microstructure suggests, however, to choose several crystal orientations, which are representative for typical grains in a polycrystal and better agreement has then been found [34].

In applying Eq. (2) $\alpha$ depends on the density and arrangement of dislocations. In the example above $\alpha$ has been taken to be a constant (0.24) and the dislocation density has been calculated as the sum of densities stored in the GNBs and the IDBs, based on the assumption that resistance of the boundaries to glide is determined by dislocationdislocation interactions [48]. However, as the misorientation angle increases with a much faster rate for GNBs than for IDBs, the GNB resistance to glide with increasing strain may approach that of grain boundaries while the IDBs having much smaller angles may continue to contribute via dislocation-dislocation interaction. Such a partial change in hardening mechanism related to the microstructural evolution may have direct implication for the hardening at large strain.

\section{Future}

Important progress in characterization and analysis of dislocation patterns originates from the introduction of new characterization techniques with increasing resolution and also with the possibility of performing dynamic experiments in 3D [49]. An example is the application of high energy synchrotron radiation which has allowed dislocation structures in their initial stages to be evaluated based on X-ray peak profiles for the individual bulk grains [50], Another example is the mapping of size and orientations of grains and cells on length scales down to 1-5 $\mu \mathrm{m}$, with a future possibility of reducing the scale to about $100 \mathrm{~nm}[51]$. The application of such new techniques in combination with SEM, TEM and HREM will elucidate not only the mechanism leading to dislocation patterning but also the coupling between microstructures, texture and hardening during plastic deformation of metals.

\section{Conclusion}

Classification and characterization of microstructural features form the basis for the identification of dislocation patterns, which have been analyzed in aluminium tensile deformed at room temperature in stage III. Co-existence of two patterns has been found in all orientations within the stereographic triangle, however, with different characteristics pointing to a dominating influence of the slip pattern. As to the technical relevance $\lceil 1\rceil$ a clear resemblance has been found between the dislocation patterning and the stress-strain behaviour of grains or crystals of different crystallographic orientations.

\begin{tabular}{|l|}
\hline Field Code Changed \\
\hline Deleted: $[31]$ \\
\hline Deleted: $[29,32]$ \\
\hline Field Code Changed \\
\hline Field Code Changed \\
\hline Deleted: $[31]$ \\
\hline
\end{tabular}

Deleted: [33]

Field Code Changed

\begin{tabular}{|c|}
\hline Field Code Changed \\
\hline Deleted: [34] \\
\hline Field Code Changed \\
\hline Deleted: [35] \\
\hline Deleted: [36] \\
\hline Field Code Changed \\
\hline Deleted: [1] \\
\hline Deleted: Side \\
\hline Deleted: a \\
\hline Deleted: 19 \\
\hline Deleted: 18 \\
\hline $\begin{array}{l}\text { Deleted: http://mc.manuscriptcentral.co } \\
\text { m/LongRequest/pm- } \\
\text { pml?TAG_ACTION=DOWNLOAD_FIL } \\
\text { E\&DOCUMENT_ID=1027263\&FILE_T } \\
\text { O_DOWNLOAD=10771839\&FILE_KE } \\
\text { Y=429685512\&DOWNLOAD=TRUE\& } \\
\text { FILE_TYPE=ORIG_DOCUMENT }\end{array}$ \\
\hline $\begin{array}{l}\text { Deleted: M:\AFM-4DINiels } \\
\text { Hansenlpapers } 12005 \backslash 09 \text { Phil Mag } \\
\text { Navarro - Grain orientationlREVised- } \\
\text { Grain Orientation and dislocation } \\
\text { configurations.doc }\end{array}$ \\
\hline $\begin{array}{l}\text { Deleted: M:\AFM-4DWNiels } \\
\text { Hansen\papers\2005\09 Phil Mag } \\
\text { Navarro - Grain orientation\GW-Grain } \\
\text { Orientation and dislocation } \\
\text { configurations.doc }\end{array}$ \\
\hline Deleted: 17 February 2006 15:25 \\
\hline Deleted: $2 / 17 / 2006$ 3:25:00 PM \\
\hline Deleted: $04-10-2005$ 14:58 \\
\hline
\end{tabular}




\section{Acknowledgement}

The authors gratefully acknowledge the Danish National Research Foundation for supporting the Center for Fundamental Research: Metal Structures in Four Dimensions within which this work was performed. Discussions with A. Godfrey, D.A. Hughes, D. Juul Jensen, Q. Liu, B. Ralph and J.A. Wert are gratefully acknowledged. A special thanks to Ms. Eva Nielsen for assistance with the manuscript.

Deleted: Side

Deleted: a

Deleted: 19

Deleted: 18

Deleted: http://mc.manuscriptcentral.co $\mathrm{m} /$ LongRequest $/ \mathrm{pm}$ -

pml?TAG_ACTION=DOWNLOAD_FIL

E\&DOCUMENT_ID $=1027263 \&$ FILE_T

O_DOWNLOAD $=10771839 \&$ FILE_KE

$\mathrm{Y}=429685512 \&$ DOWNLOAD=TRUE\&

FILE_TYPE=ORIG_DOCUMENT

Deleted: M:LAFM-4DINiels

Hansenlpapers $2005 \backslash 09$ Phil Mag

Navarro - Grain orientationไREVised-

Grain Orientation and dislocation configurations.doc

Deleted: M:IAFM-4DINiels

Hansen\papers\2005\09 Phil Mag

Navarro - Grain orientationlGW-Grain

Orientation and dislocation

configurations.doc

Deleted: 17 February 2006 15:25

Deleted: 2/17/2006 3:25:00 PM

Deleted: 04-10-2005 14:58 


\section{Figure Captions}

Fig. 1
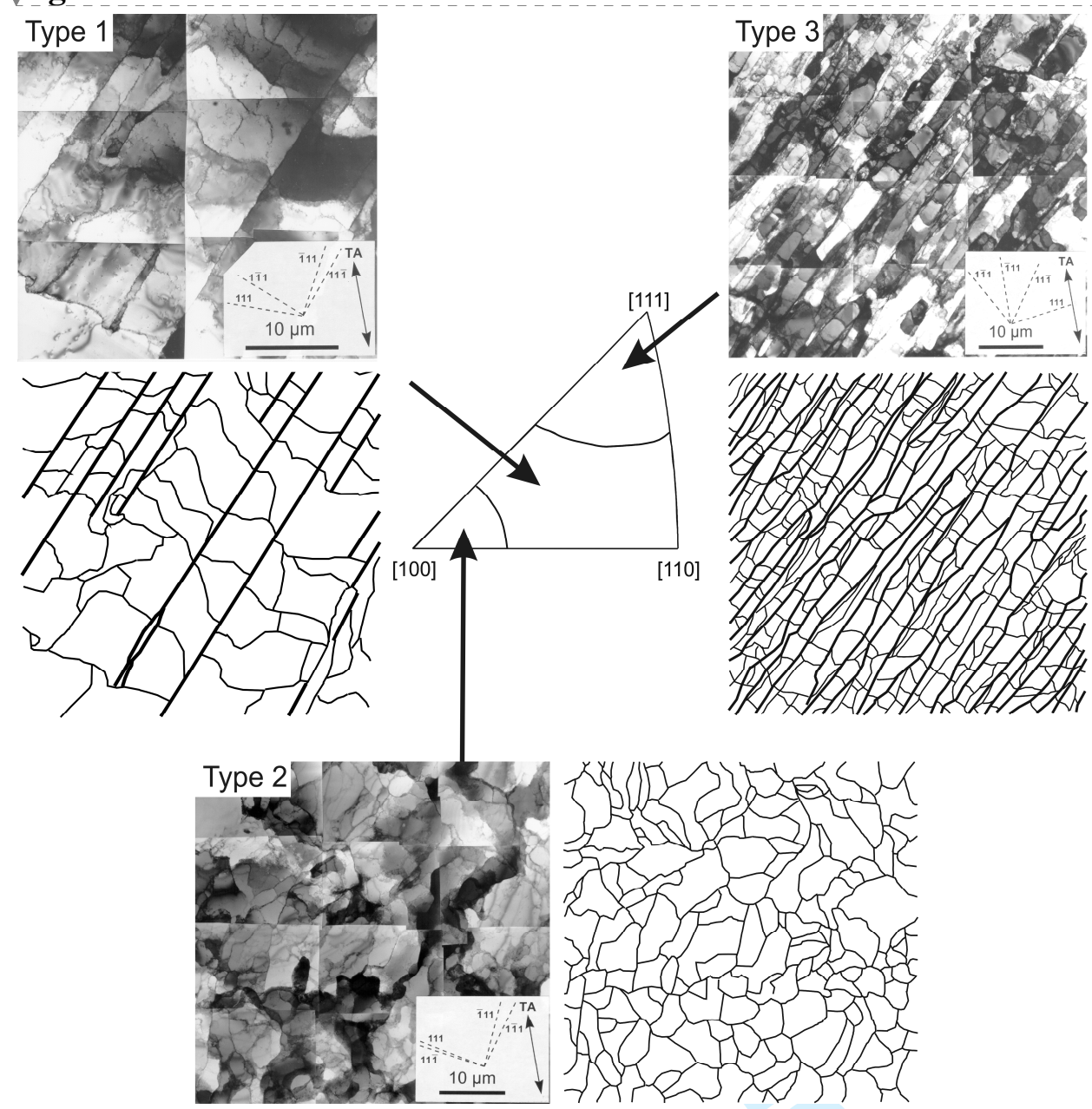

Microstructural types (see text) in grains of different orientations in polycrystalline pure aluminium $(99.99 \%)$ deformed in tension in the strain range from 0.05 to 0.34 . [26,27]. The micrographs shown in this figure were taken at a tensile strain of 0.14 .
Deleted: $\langle s p>$

Deleted: <sp>

Deleted: Microstructural types (see

text) in grains of different orientations in polycrystalline pure aluminium $(99.99 \%)$ deformed in tension in the strain range from 0.05 to 0.34

Field Code Changed

Deleted: $[9,10]$

Deleted: Side

Deleted: a

Deleted: 19

Deleted: 18

Deleted: http://mc.manuscriptcentral.co $\mathrm{m} /$ LongRequest $/ \mathrm{pm}$ -

pml?TAG_ACTION=DOWNLOAD_FIL

E\&DOCUMENT_ID $=1027263 \&$ FILE_T

O_DOWNLOAD $=10771839 \&$ FILE_KE

$Y=429685512 \& D O W N L O A D=T R U E \&$

FILE_TYPE=ORIG_DOCUMENT

Deleted: M:\AFM-4DINiels

Hansenlpapers 12005109 Phil Mag

Navarro - Grain orientationไREVised

Grain Orientation and dislocation configurations.doc

Deleted: M:\AFM-4DINiels

Hansenlpapers\2005109 Phil Mag

Navarro - Grain orientationlGW-Grain

Orientation and dislocation configurations.doc

Deleted: 17 February 2006 15:25

Deleted: 2/17/2006 3:25:00 PM

Deleted: 04-10-2005 14:58 
Fig. 2

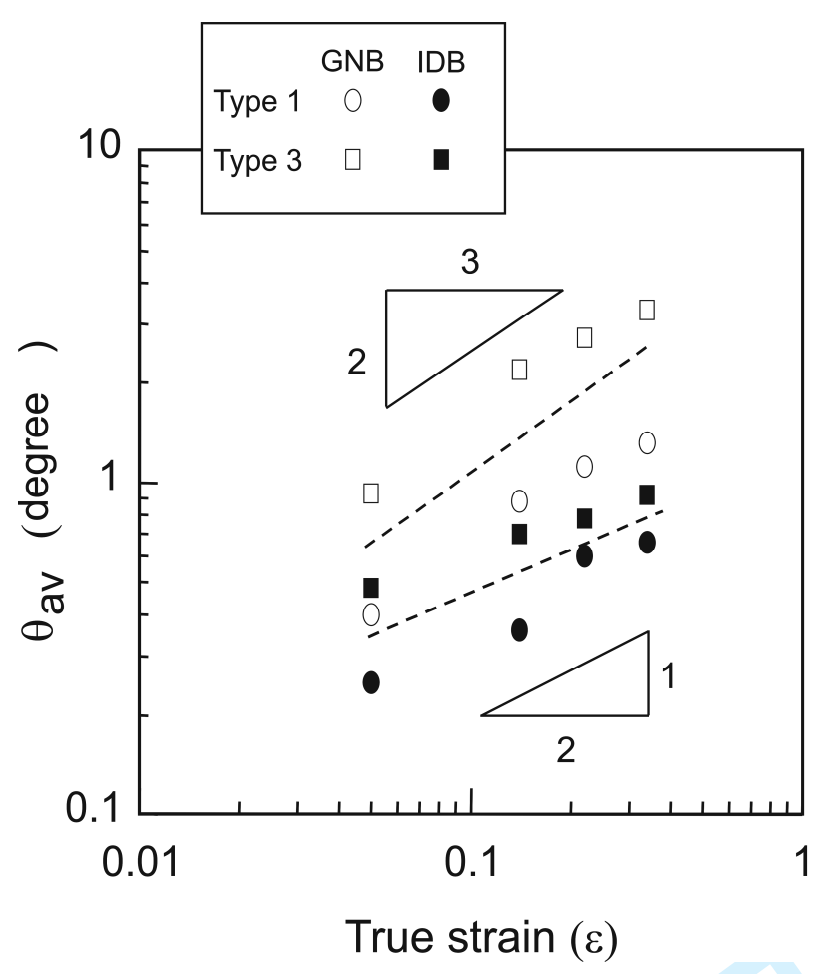

Average misorientation angles as a function of strain for IDBs and GNBs in Type 1 and Type 3 grains, respectively. The two dashed lines are drawn through average values for IDBs and GNBs, respectively, illustrating their different rate of angular evolution with increasing strain. The two triangles are guides to the eye.

Deleted: Side

Deleted: a

Deleted: 19

Deleted: 18

Deleted: http://mc.manuscriptcentral.co $\mathrm{m} /$ LongRequest/pm-

pmI?TAG ACTION=DOWNLOAD FIL

E\&DOCUMENT_ID $=1027263 \&$ FILE_T

O_DOWNLOAD $=10771839 \&$ FILE_KE

$\mathrm{Y}=429685512 \& D O W N L O A D=T R U E \&$

FILE_TYPE=ORIG_DOCUMENT

Deleted: M:IAFM-4DINiels

Hansenlpapers12005109 Phil Mag

Navarro - Grain orientation|REVised-

Grain Orientation and dislocation configurations.doc

Deleted: M:LAFM-4DINiels

Hansentpapers 2005109 Phil Mag

Navarro - Grain orientationlGW-Grain

Orientation and dislocation

configurations.doc

Deleted: 17 February 2006 15:25

Deleted: 2/17/2006 3:25:00 PM

Deleted: 04-10-2005 14:58 
Fig. 3

A TEM image and a sketch of a microstructure in transverse plan view in a grain in the [100] region in a specimen deformed to a tensile strain of $\varepsilon=0.34$. The image shows regions with black and white contrasts and an overall structure of almost equiaxed cells. The orientation difference between the regions is typically in the range $2-6^{\circ}$ whereas the orientation difference between the cells within the regions is less than $2^{\circ}$ (see text). The histogram shows the distribution of misorientation angles with a much wider spread than observed for the IDBs in Type 1 or Type 3 grains. 
Fig. 4

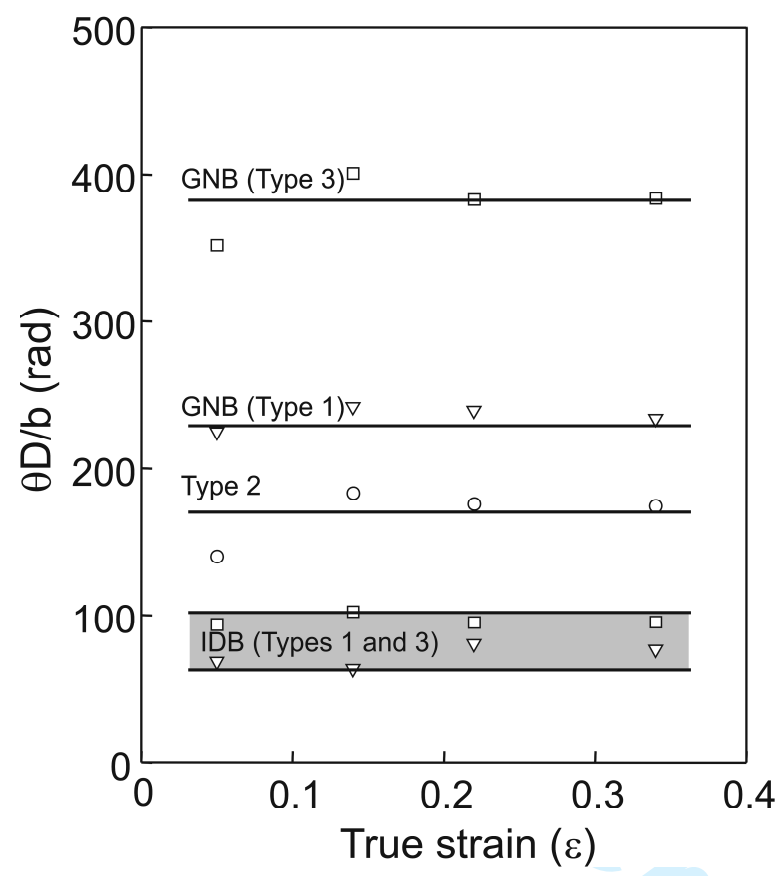

Similitude expressed by the relationship $\theta \mathrm{D} / \mathrm{b}$ for GNBs and IDBs in Type 1 and Type 3 grains and for all boundaries in Type 2 grains [38],

Deleted: http://mc.manuscriptcentral.co $\mathrm{m} /$ LongRequest/pm-

pml?TAG_ACTION=DOWNLOAD_FIL

pml?TAG_ACTION=DOWNLOAD_FIL

O_DOWNLOAD $=10771839 \&$ FILE_KE

$\mathrm{Y}=429685512 \&$ DOWNLOAD=TRUE\&

FILE_TYPE=ORIG_DOCUMENT

Deleted: M:\AFM-4DINiels

Hansenlpapers\2005109 Phil Mag

Navarro - Grain orientationlREVised-

Grain Orientation and dislocation configurations.doc

Deleted: M:LAFM-4DINiels

Hansenlpapers\2005109 Phil Mag

Navarro - Grain orientationไGW-Grain

Orientation and dislocation

configurations.doc

Deleted: 17 February 2006 15:25

Deleted: 2/17/2006 3:25:00 PM

Deleted: 04-10-2005 14:58 
Stereographic triangle showing the orientation of the tensile axis for grains with concentrated slip predicted from the Taylor solution with most primary slip (grey area). Grey area roughly corresponds to Type 1 and white area to Type 3 . Black area corresponds to Type 2, which does not contains GNBs.

\section{Deleted: 1}

Deleted: Side

Deleted: a

Deleted: 19

Deleted: 18

Deleted: http://mc.manuscriptcentral.co $\mathrm{m} /$ LongRequest/pm-

pml?TAG_ACTION=DOWNLOAD_FIL

E\&DOCUMENT_ID $=1027263 \&$ FILE_T

O_DOWNLOAD $=10771839 \&$ FILE_KE

$Y=429685512 \& D O W N L O A D=T R U E \&$

FILE_TYPE=ORIG_DOCUMENT

Deleted: M:IAFM-4DINiels

Hansenlpapers $2005 \backslash 09$ Phil Mag

Navarro - Grain orientationไREVised-

Grain Orientation and dislocation configurations.doc

Deleted: M:LAFM-4DINiels

Hansenlpapers\2005109 Phil Mag

Navarro - Grain orientationlGW-Grain

Orientation and dislocation

configurations.doc

Deleted: 17 February 2006 15:25

Deleted: 2/17/2006 3:25:00 PM

Deleted: 04-10-2005 14:58 
Fig. 6

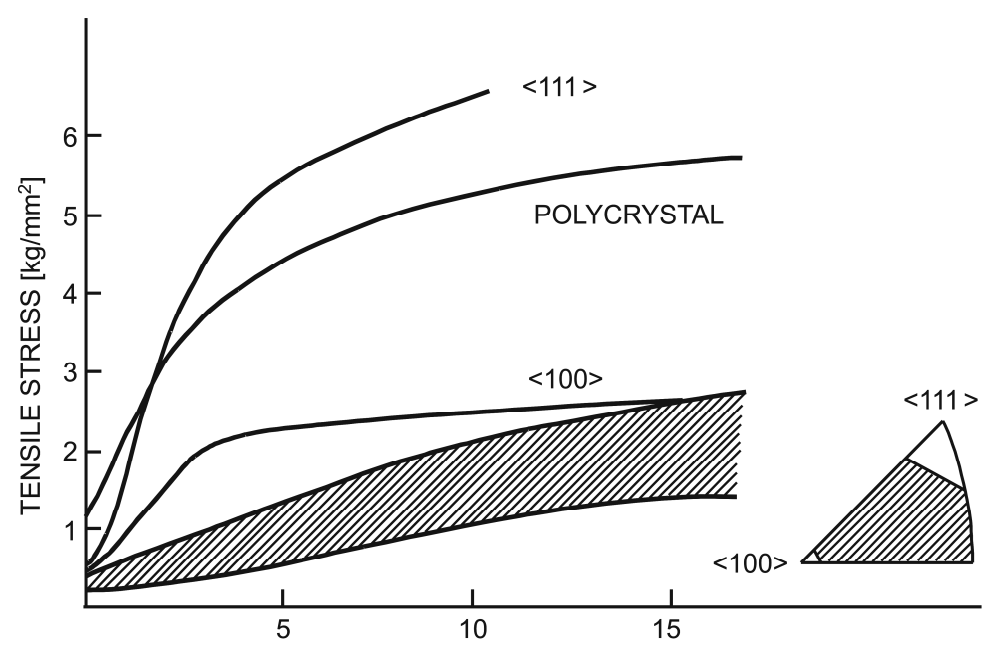

Strain hardening in tension for single crystals of various orientations and a polycrystal [45].

Deleted: $[29,30]$

Deleted: Side

Deleted: a

Deleted: 19

Deleted: 18

Deleted: http://mc.manuscriptcentral.co $\mathrm{m} /$ LongRequest/pm-

pml?TAG_ACTION=DOWNLOAD_FIL

E\&DOCUMENT_ID $=1027263 \&$ FILE_T

O_DOWNLOAD $=10771839 \&$ FILE_KE

$\mathrm{Y}=429685512 \&$ DOWNLOAD=TRUE\&

FILE_TYPE=ORIG_DOCUMENT

Deleted: M:IAFM-4DINiels

Hansen papers $2005 \backslash 09$ Phil Mag

Navarro - Grain orientation $\backslash R E V$ ised-

Grain Orientation and dislocation configurations.doc

Deleted: M:LAFM-4DINiels

Hansen\papers\2005109 Phil Mag

Navarro - Grain orientationlGW-Grain

Orientation and dislocation

configurations.doc

Deleted: 17 February 2006 15:25

Deleted: 2/17/2006 3:25:00 PM

Deleted: 04-10-2005 14:58 


\section{$\underline{\text { Table } 1}$}

Volume fraction of texture components [34].

\begin{tabular}{|c|l|l|l|}
\hline$\underline{\text { Strain }}$ & $\underline{[100]}$ & $\underline{[111]}$ & $\underline{[110]}$ \\
\hline$\underline{0}$ & $\underline{0.280}$ & $\underline{0.132}$ & $\underline{0.100}$ \\
\hline$\underline{0.34}$ & $\underline{0.277}$ & $\underline{0.226}$ & $\underline{0.033}$ \\
\hline
\end{tabular}

Deleted: http://mc.manuscriptcentral.co $\mathrm{m} /$ LongRequest/pm-

pml?TAG_ACTION=DOWNLOAD_FIL

E\&DOCUMENT_ID $=1027263 \&$ FILE_T

O_DOWNLOAD $=10771839 \&$ FILE_KE

$\mathrm{Y}=429685512 \&$ DOWNLOAD=TRUE\&

FILE_TYPE=ORIG_DOCUMENT

Deleted: M:\AFM-4DINiels

Hansenlpapers 12005109 Phil Mag
Navarro - Grain orientationlREVised-

Grain Orientation and dislocation configurations.doc

Deleted: M:LAFM-4DINiels

Hansenlpapers\2005\09 Phil Mag

Navarro - Grain orientationlGW-Grain

Orientation and dislocation

configurations.doc

Deleted: 17 February 2006 15:25

Deleted: 2/17/2006 3:25:00 PM

Deleted: $04-10-2005$ 14:58 
$\underline{\text { References }}$

[1] F.R.N.Nabarro, Mater. Sci. Engng. A 2001, 317, 12.

[2] D.A.Hughes, N.Hansen, Plastic Deformation Structures, in: ASM Handbook, Vol. 9; Metallography and Microstructures, ASM International, Materials Park, Ohio, USA, 2004, 292.

[3] J.W.Steeds, Proc. Roy. Soc. A 1966, 292, 343.

[4] Z.S.Basinski, Discussions of the Faraday Society 196493.

[5] U.Essmann, Physica Status Solidi 1965, 12, 723.

[6] D.A.Hughes, S.M.A.Khan, A.Godfrey, H.M.Zbib, Mater. Sci. Engng. A 2001, 309, 220.

[7] P.J.Jackson, D.Kuhlmann-Wilsdorf, Scripta Metall. 1982, 16, 105.

[8] P.J.Jackson, Scripta Metall. 1983, 17, 199.

[9] B.Bay, N.Hansen, D.A.Hughes, D.Kuhlmann-Wilsdorf, Acta Metall. Mater. 1992, 40, 205.

[10] D.Kuhlmann-Wilsdorf, N.Hansen, Scripta Metall. Mater. 1991, 25, 1557.

[11] J.A.Wert, in Proceedings: 19th Risø Int. Symp. on Mat. Science Modelling of Structure and Mechanics of Materials from Microscale to Product.

J.V.Carstensen et al. (Eds.), Risø National Laboratory, Roskilde, Denmark, 1998, 573.

[12] D.A.Hughes, N.Hansen, Acta Mater. 2000, 48, 2985.

[13] D.A.Hughes, N.Hansen, D.J.Bammann, Scripta Mater. 2003, 48, 147.

[14] J.F.Nye, Acta Metall. 1953, 1, 153.

[15] M.F.Ashby, Philos. Mag. 1970, 21, 399.

[16] The mechanical properties of materials, A.H.Cottrell, Wiley, New York, 1964.

[17] Y.Kawasaki, Jpn. J. Appl. Phys. 1979, 18, 1429.

[18] Y.Kawasaki, T.Takeuchi, Scripta Metall. 1980, 14, 183.

[19] F.Inoko, T.Okada, M.Tagami, K.Kashihara, in Proceedings: 20th Ris $\varnothing$ Int. Symp. on Mat. Science Deformation-Induced Microstructures: Analysis and Relation to Properties. J.B.Bilde-Sørensen et al. (Eds.), Roskilde, 1999, 375.

[20] A.Godfrey, D.A.Hughes, Acta Mater. 2000, 48, 1897.

\begin{tabular}{|l|}
\hline Deleted: Side \\
\hline Deleted: a \\
\hline Deleted: 19 \\
\hline Deleted: 18 \\
\hline Deleted: http://mc.manuscriptcentral.co \\
m/LongRequest/pm- \\
pml?TAG_ACTION=DOWNLOAD_FIL \\
E\&DOCUMENT_ID=1027263\&FILE_T \\
O_DOWNLOAD=10771839\&FILE_KE \\
Y=429685512\&DOWNLOAD=TRUE\& \\
FILE_TYPE=ORIG_DOCUMENT \\
\hline Deleted: M:\AFM-4DINiels \\
Hansenlpapers/2005109 Phil Mag \\
Navarro - Grain orientationlREVised- \\
Grain Orientation and dislocation \\
configurations.doc
\end{tabular}

Deleted: M:LAFM-4DINiels

Hansen\papers\2005\09 Phil Mag

Navarro - Grain orientation $\backslash$ GW-Grain

Orientation and dislocation

configurations.doc

Deleted: 17 February 2006 15:25

Deleted: 2/17/2006 3:25:00 PM

Deleted: 04-10-2005 14:58 
[21] Q.Liu, N.Hansen, Proc. Roy. Soc. A 1998, 454, 2555.

[22] X.Huang, N.Hansen, Mater. Sci. Engng. A 2004, 387-89, 186.

[23] V.Randle, N.Hansen, D.Juul Jensen, Philos. Mag. A 1996, 73, 265.

[24] C.Y.J.Barlow, B.Bay, N.Hansen, Philos. Mag. A 1985, 51, 253.

[25] C.Thorning, M.A.J.Somers, J.A.Wert, Mater. Sci. Engng. A 2005, 397, 215.

[26] X.Huang, N.Hansen, Scripta Mater. 1997, 37, 1.

[27] N.Hansen, X.Huang, D.A.Hughes, Mater. Sci. Engng. A 2001, 317, 3.

[28] W.Pantleon, Acta Mater. 1998, 46, 451.

[29] W.Pantleon, Mater. Sci. Engng. A 2005, 400, 118.

[30] W.Pantleon, Journal of Materials Research 2002, 17, 2433.

[31] A.S.Argon, P.Haasen, Acta Metall. Mater. 1993, 41, 3289.

[32] F.R.N.Nabarro, Scripta Metall. Mater. 1994, 30, 1085.

[33] F.R.N.Nabarro, D.Kuhlmann-Wilsdorf, Scripta Mater. 1996, 35, 1331.

[34] N.Hansen, X.Huang, Acta Mater. 1998, 46, 1827.

[35] D.A.Hughes, D.C.Chrzan, Q.Liu, N.Hansen, Physical Review Letters 1998, 81, 4664.

[36] W.Pantleon, N.Hansen, Acta Mater. 2001, 49, 1479.

[37] D.Kuhlmann-Wilsdorf, Phys. Status Solidi (a) 1995, 149, 225.

[38] N.Hansen, D.A.Hughes, Phys. Status Solidi (a) 1995, 149, 155.

[39] M.Wilkens, T.Ungar, H.Mughrabi, Phys. Status Solidi (a) 1987, 104, 157.

[40] H.Mughrabi, T.Ungar, W.Kienle, M.Wilkens, Philos. Mag. A 1986, 53, 793.

[41] J.A.Wert, X.Huang, Philos. Mag. 2003, 83, 969.

[42] G.Winther, D.Juul Jensen, N.Hansen, Acta Mater. 1997, 45, 5059.

[43] G.Winther, Acta Mater. 2003, 51, 417.

[44] G.Winther, L.Margulies, S.Schmidt, H.F.Poulsen, Acta Mater. 2004, 52, 2863.

[45] U.F.Kocks, Acta Metall. 1960, 8, 345.

[46] W.Staubwasser, Acta Metall. 1959, 7, 43.

[47] U.F.Kocks, Metall. Trans. 1970, 1, 1121. 
[49] D.Juul Jensen, H.F.Poulsen, A.Kvik, Encyclopedia of Materials: Science and Technology, updates, in: Elsevier, Oxford, 2005.

[50] W.Pantleon, H.F.Poulsen, J.Almer, U.Lienert, Mater. Sci. Engng. A 2004, 387, 339.

[51] L.Margulies, H.F.Poulsen, in Proceedings: 25th Ris $\varnothing$ Int. Symp. on Mat. Science Evolution of Deformation Microstructures in 3D. C.Gundlach et al. (Eds.), Ris $\emptyset$ National Laboratory, Roskilde, Denmark, 2004, 61.

II

[1] . F.R.N.Nabarro, Mater. Sci.

Engng. A 2001, 317, 12.I

[2] D.A.Hughes, N.Hansen, Plastic

Deformation Structures, in: ASM

Handbook, Vol. 9; Metallography and

Microstructures, ASM International,

Materials Park, Ohio, USA, 2004, 292.II

[3] . J.W.Steeds, Proc. Roy. Soc. A 1966, 292, 343. IL

[4] . B.Bay, N.Hansen, D.A.Hughes,

D.Kuhlmann-Wilsdorf, Acta Metall.

Mater. 1992, 40, 205.II

[5] D.Kuhlmann-Wilsdorf, N.Hansen, Scripta Metall. Mater. 1991, 25, 1557.II

[6] J.A.Wert, in Proceedings: 19th

Ris $\varnothing$ International Symposium on

Materials Science Modelling of Structure

and Mechanics of Materials from

Microscale to Product. J.V.Carstensen et

al. (Eds.), Risø National Laboratory,

Roskilde, Denmark, 1998, 573.II

. [7] - D.A.Hughes, N.Hansen, Acta Mater. 2000, 48, 2985.II

. [8] . X.Huang, N.Hansen, Mater. Sci. Engng. A 2004, 387-89, 186.I

[9] . X.Huang, N.Hansen, Scripta

Mater. 1997, 37, 1.II

[10] N.Hansen, X.Huang,

D.A.Hughes, Mater. Sci. Engng. A 2001,

317, 3.II

[11] . W.Pantleon, Acta Mater. 1998 46, 451.II

- [12] . W.Pantleon, Mater. Sci. Engng. A 2005, 400, 118.II

[13] . W.Pantleon, Journal of Materials Research 2002, 17, 2433.II

[14] . A.S.Argon, P.Haasen, Acta Metall. Mater. 1993, 41, 3289.II

[15] F.R.N.Nabarro, Scripta Metall. Mater. 1994, 30, 1085.I

[16] . F.R.N.Nabarro, D.Kuhlmann-

Wilsdorf, Scripta Mater. 1996, 35, 1331.II

. [17] D.A.Hughes, D.C.Chrzan, Q.Liu, N.Hansen, Phys. Rev. Lett. 1998, 81, 4664.II

[18] . W.Pantleon, N.Hansen, A ... [1]

Deleted: Side

Deleted: a

Deleted: 19

Deleted: 18

Deleted: http://mc.manuscriptcentral.co $\mathrm{m} /$ LongRequest/pm-

pml?TAG_ACTION=DOWNLOAD_FIL E\&DOCUMENT_ID=1027263\&FILE_T O_DOWNLOAD $=10771839 \&$ FILE_KE

$\mathrm{Y}=429685512 \& D O W N L O A D=T[$... [2]

Deleted: M:\AFM-4DINiels

Hansenlpapers\2005109 Phil Mag

Navarro - Grain orientationไREVised

Grain Orientation and dislocation configurations.doc

Deleted: M:IAFM-4DINiels

Hansen\papers\2005109 Phil Mag

Navarro - Grain orientationไGW-Grain

Orientation and dislocation

configurations.doc

Deleted: 17 February 2006 15:25

Deleted: 2/17/2006 3:25:00 PM

Deleted: 04-10-2005 14:58 
[1] F.R.N.Nabarro, Mater. Sci. Engng. A 2001, 317, 12.

[2] D.A.Hughes, N.Hansen, Plastic Deformation Structures, in: ASM Handbook, Vol. 9; Metallography and Microstructures, ASM International, Materials Park, Ohio, USA, 2004, 292.

[3] J.W.Steeds, Proc. Roy. Soc. A 1966, 292, 343.

[4] B.Bay, N.Hansen, D.A.Hughes, D.Kuhlmann-Wilsdorf, Acta Metall. Mater. 1992, 40, 205.

[5] D.Kuhlmann-Wilsdorf, N.Hansen, Scripta Metall. Mater. 1991, 25, 1557.

[6] J.A.Wert, in Proceedings: 19th Ris $\varnothing$ International Symposium on Materials Science Modelling of Structure and Mechanics of Materials from Microscale to Product. J.V.Carstensen et al. (Eds.), Ris $\varnothing$ National Laboratory, Roskilde, Denmark, 1998, 573.

[7] D.A.Hughes, N.Hansen, Acta Mater. 2000, 48, 2985.

[8] X.Huang, N.Hansen, Mater. Sci. Engng. A 2004, 387-89, 186.

[9] X.Huang, N.Hansen, Scripta Mater. 1997, 37, 1.

[10] N.Hansen, X.Huang, D.A.Hughes, Mater. Sci. Engng. A 2001, 317, 3.

[11] W.Pantleon, Acta Mater. 1998, 46, 451.

[12] W.Pantleon, Mater. Sci. Engng. A 2005, 400, 118.

[13] W.Pantleon, Journal of Materials Research 2002, 17, 2433.

[14] A.S.Argon, P.Haasen, Acta Metall. Mater. 1993, 41, 3289.

[15] F.R.N.Nabarro, Scripta Metall. Mater. 1994, 30, 1085.

[16] F.R.N.Nabarro, D.Kuhlmann-Wilsdorf, Scripta Mater. 1996, 35, 1331.

[17] D.A.Hughes, D.C.Chrzan, Q.Liu, N.Hansen, Phys. Rev. Lett. 1998, 81, 4664.

[18] W.Pantleon, N.Hansen, Acta Mater. 2001, 49, 1479.

[19] D.Kuhlmann-Wilsdorf, Phys. Status Solidi (a) 1995, 149, 225.

[20] N.Hansen, D.A.Hughes, Phys. Status Solidi (a) 1995, 149, 155.

[21] C.Thorning, M.A.J.Somers, J.A.Wert, Mater. Sci. Engng. A 2005, 397, 215.

[22] M.Wilkens, T.Ungar, H.Mughrabi, Phys. Status Solidi (a) 1987, 104, 157.

[23] H.Mughrabi, T.Ungar, W.Kienle, M.Wilkens, Philos. Mag. A 1986, 53, 793.

[24] G.Winther, Acta Mater. 2003, 51, 417.

[25] G.Winther, D.Juul Jensen, N.Hansen, Acta Mater. 1997, 45, 5059.

[26] G.Winther, L.Margulies, S.Schmidt, H.F.Poulsen, Acta Mater. 2004, 52, 2863.

[27] Y.Kawasaki, Jpn. J. Appl. Phys. 1979, 18, 1429.

[28] Y.Kawasaki, T.Takeuchi, Scripta Metall. 1980, 14, 183.

[29] U.F.Kocks, Acta Metall. 1960, 8, 345.

[30] W.Staubwasser, Acta Metall. 1959, 7, 43.

[31] N.Hansen, X.Huang, Acta Mater. 1998, 46, 1827.

[32] U.F.Kocks, Metall. Trans. 1970, 1, 1121.

[33] U.F.Kocks, H.Mecking, Progress in Materials Science 2003, 48, 171.

[34] D.Juul Jensen, H.F.Poulsen, A.Kvik, Encyclopedia of Materials: Science and Technology, updates, in: Elsevier, Oxford, 2005.

[35] W.Pantleon, H.F.Poulsen, J.Almer, U.Lienert, Mater. Sci. Engng. A 2004, 387, 339. 
[36] L.Margulies, H.F.Poulsen, in Proceedings: 25th Ris $\varnothing$ International Symposium on Materals Science Evolution of Deformation Microstructures in 3D. C.Gundlach et al. (Eds.), Risø National Laboratory, Roskilde, Denmark, 2004, 61.

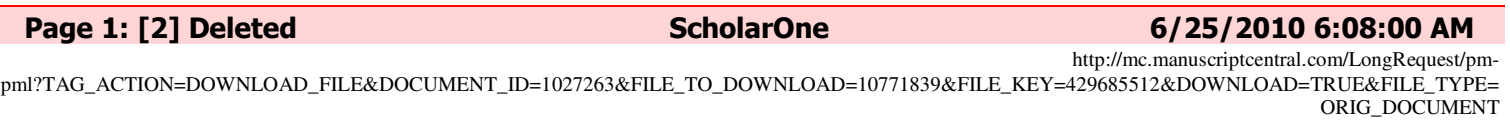




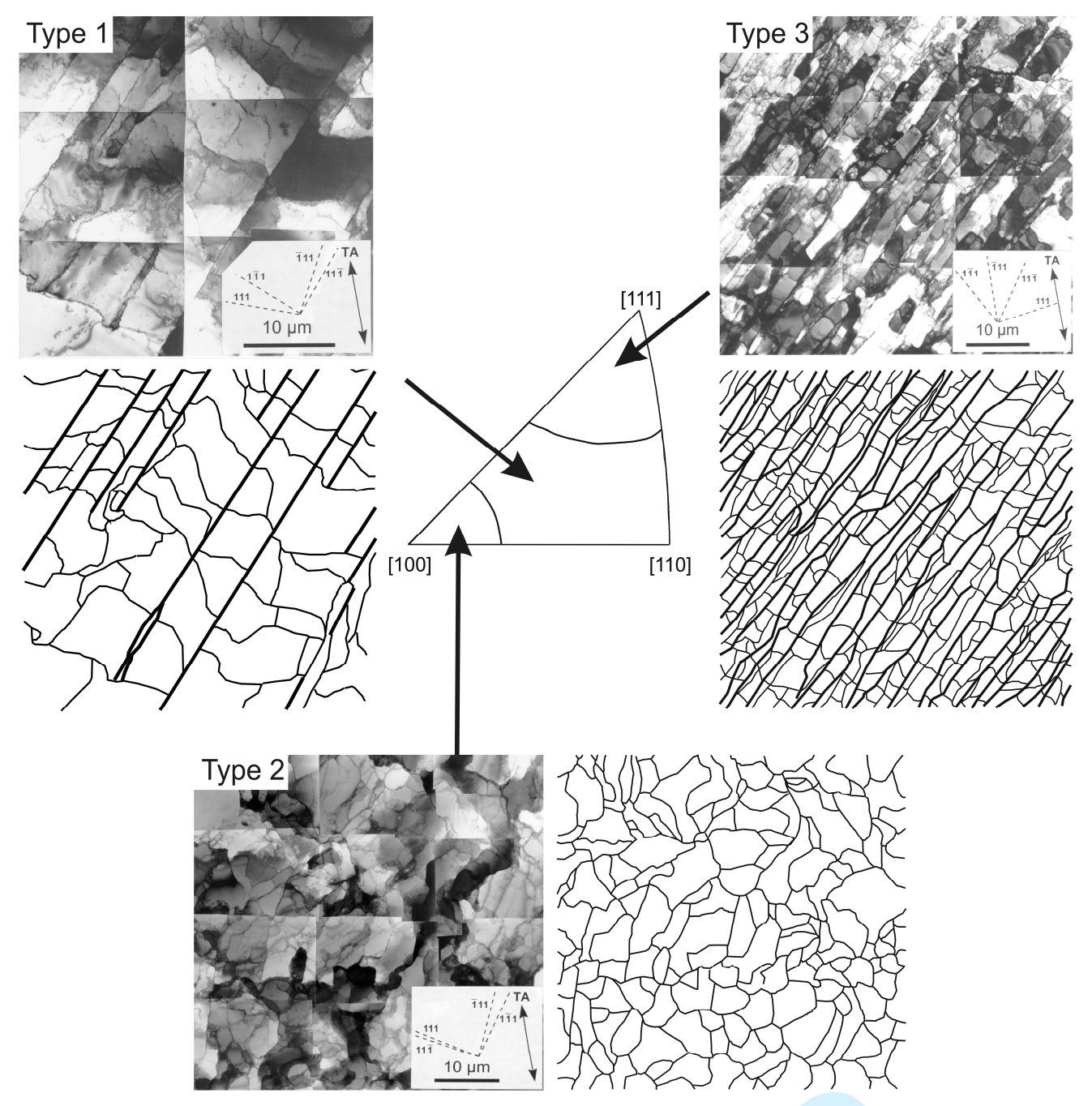




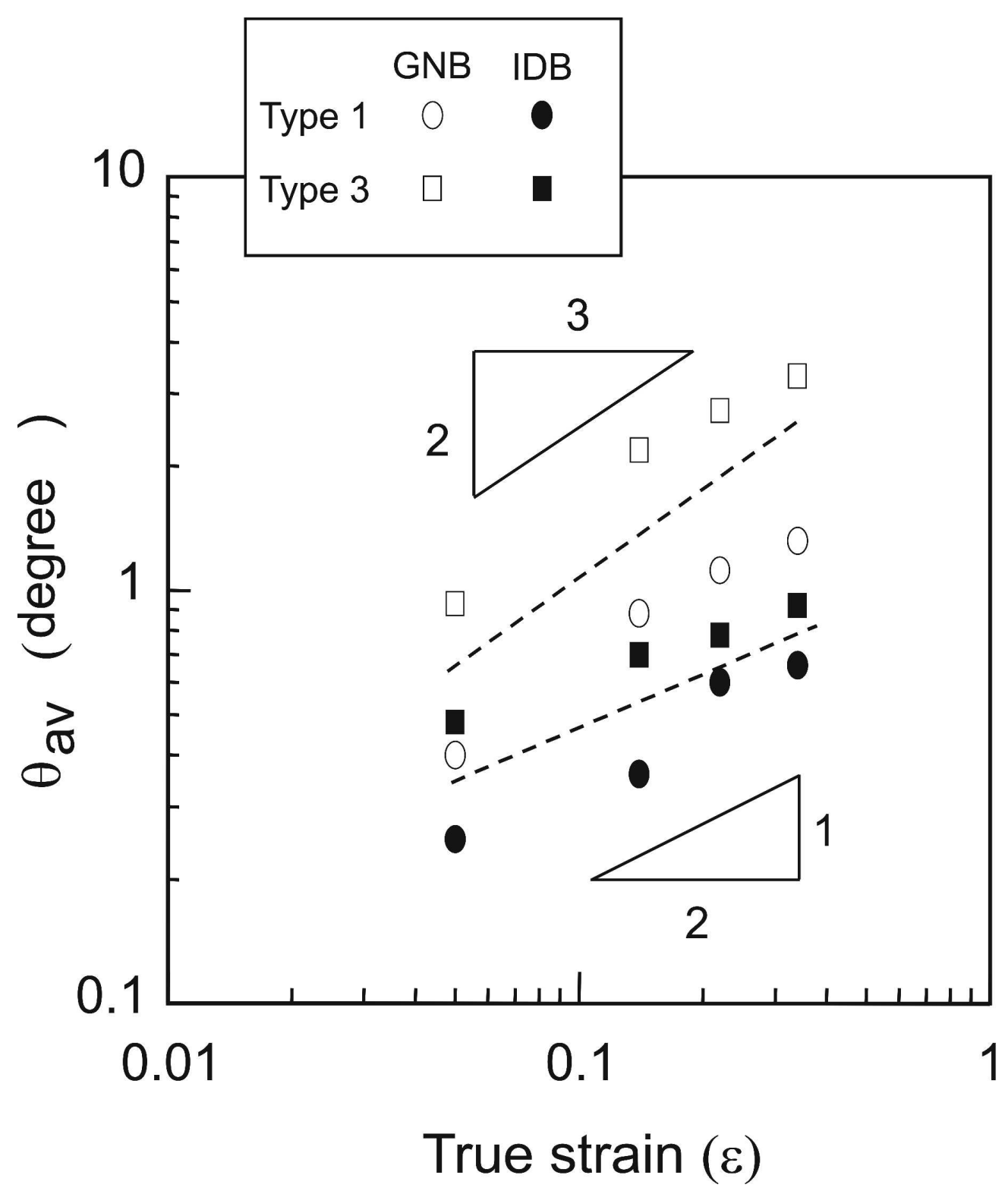

\footnotetext{
Average misorientation angles as a function of strain for IDBs and GNBs in Type 1 and Type 3 grains, respectively. The two dashed lines are drawn through average values for IDBs and GNBs, respectively, illustrating their different rate of angular evolution with increasing strain.
} 


\begin{abstract}
A TEM image and a sketch of a microstructure in transverse plan view in a grain in the [100] region in a specimen deformed to a tensile strain of $e=0.34$. The image shows regions with black and white contrasts and an overall structure of almost equiaxed cells. The orientation difference between the regions is typically in the range $2-6^{\circ}$ whereas the orientation difference between the cells within the regions is less than $2^{\circ}$ (see text). The histogram shows the distribution of misorientation angles with a much wider spread than observed for the IDBs in Type 1 or Type 3 grains.
\end{abstract}




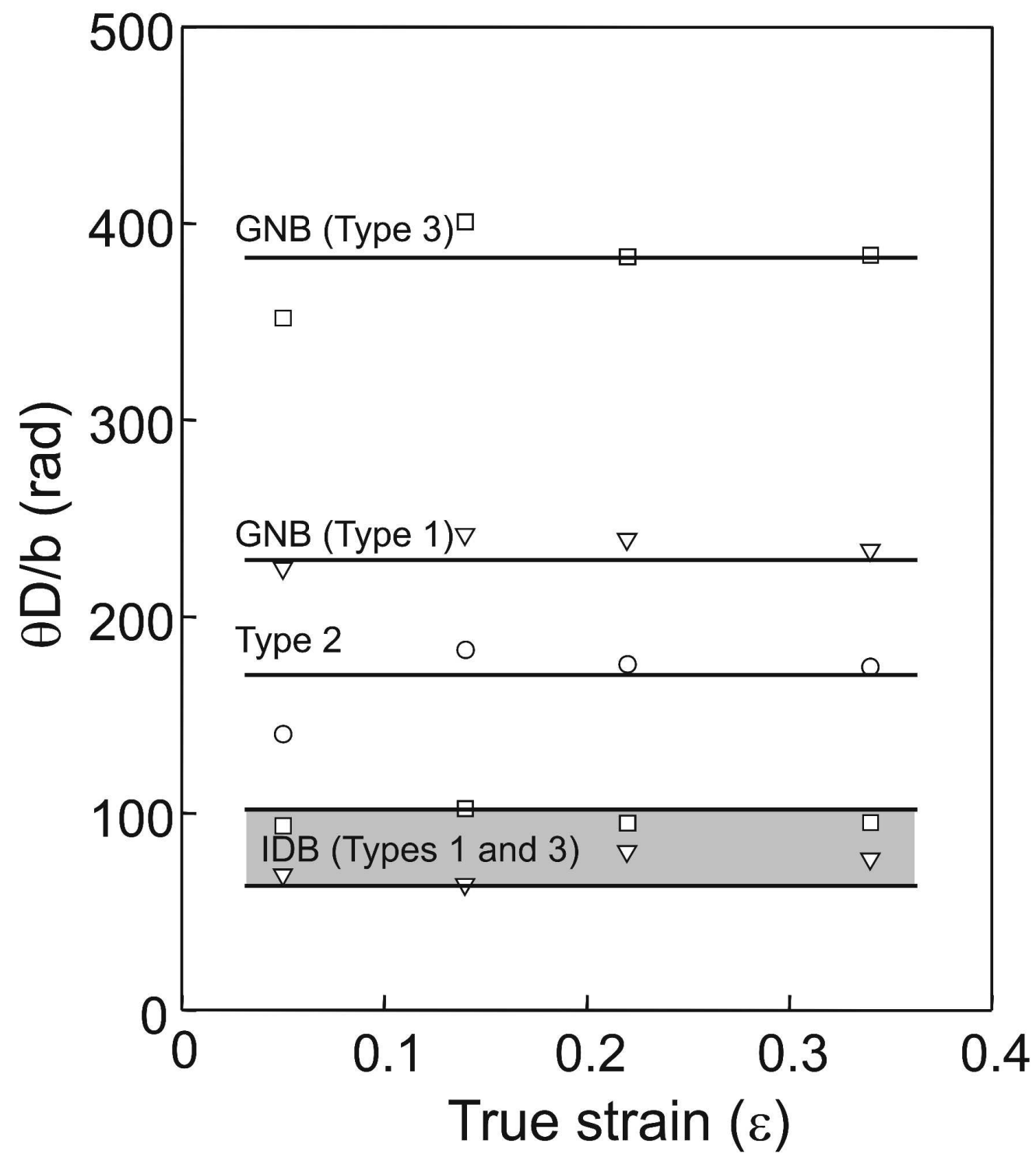

Similitude expressed by the relationship $q \mathrm{D} / \mathrm{b}$ for GNBs and IDBs in Type 1 and Type 3 grains and for all boundaries in Type 2 grains [10]. 


\section{[100].}

[110]

\section{Stereographic triangle showing the orientation of the tensile axis for grains with concentral slip} predicted from the Taylor solution with most primary slip (grey area). $123 \times 116 \mathrm{~mm}$ (96 x 96 DPI) 


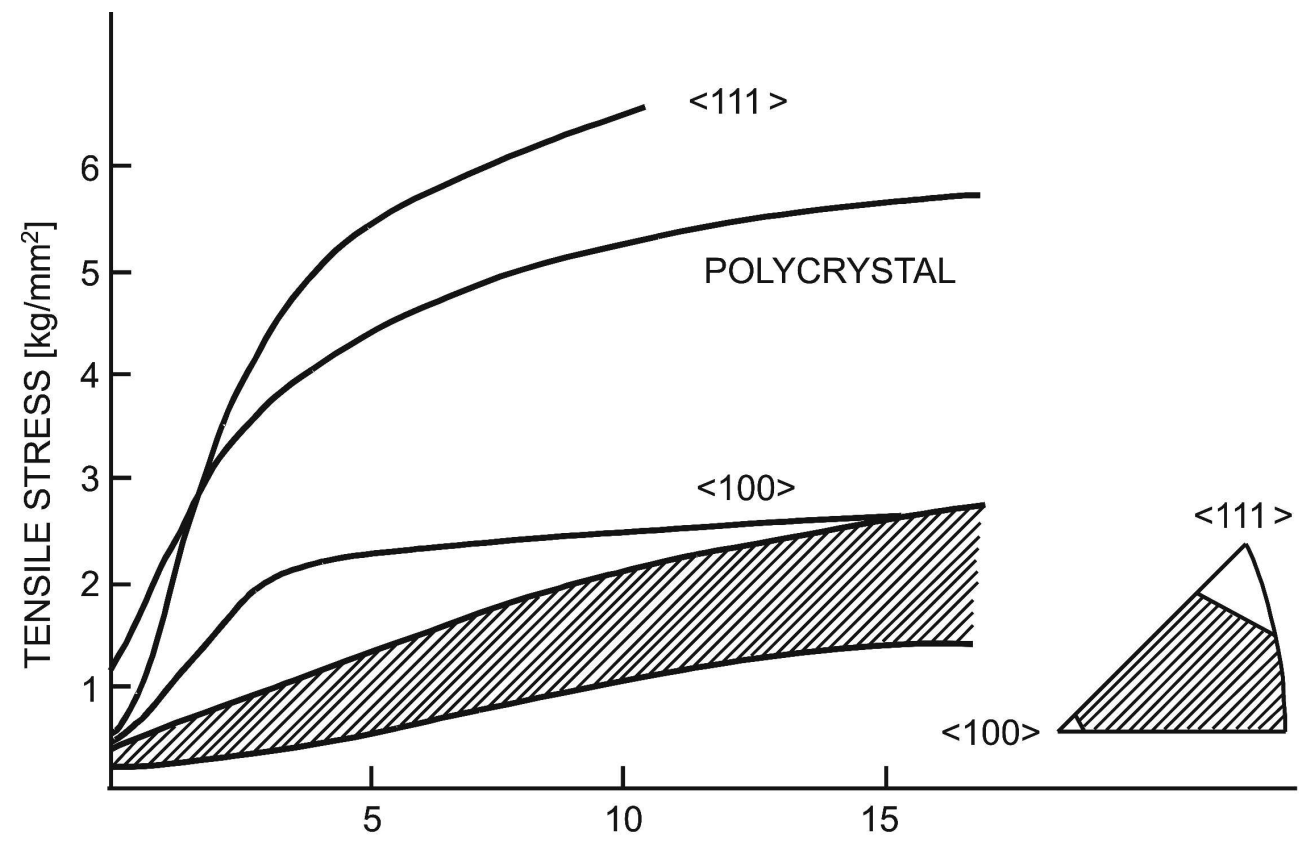

Strain hardening in tension for single crystals of various orientations and a polycrystal $[28,29]$. 